\title{
PENERAPAN PENDEKATAN SCIENTIFIC BERBASIS \\ PEMBELAJARAN AKTIF SAME DIFFERENT UNTUK \\ MENINGKATKAN HASIL BELAJAR SISWA MATA PELAJARAN PKN \\ SISWA KELAS III DI SD NEGERI 4 TANJUNG KAMAL TAHUN PELAJARAN 2018/2019
}

\author{
Kurniyati $^{1}$ \\ ${ }^{1}$ SD Negeri 2 Tanjung Kamal \\ Email: kurniyati_tk@gmail.com
}

Received: May 18, 2020 Revised: May 21, $2020 \quad$ Accepted: May 26, 2020

\begin{abstract}
ABSTRAK
Dalam proses belajar mengajar PKn di SD Negeri 4 Tanjung Kamal, terutama kelas III selama ini yang telah dilaksanakan oleh seorang guru belum mencapai kreteria, sebagian belum memenuhi KKM yang telah ditentukan. Contoh pada saat ulangan umum semester ganjil yang memenuhi KKM hanya $70 \%$. Minat belajar siswa semakin menurun karena sibuk main HP terutama pada malam hari tidak ingat belajar lagi, sehingga pada waktu proses pembelajaran berlansung ada yang mengantuk kurang memperhatikan dan kurang konsentrasi. Bila guru bertanya kebanyakan belum berani menjawab.

Dengan adanya Metode Penerapan pendekatan scientific berbasis pembelajaran aktif same different diharapkan dapat meningkatkan aktivitas dan hasil belajar. Desain penelitian menggunakan PTK. Teknik pengumpulan data berupa observasi, wawancara, tes dan dokumentasi.

Berdasarkan hasil analisa data yang telah dikemukakan di bab IV dapat diuraikan sebagai berikut: 1) Penerapan pendekatan scientific berbasis pembelajaran aktif same different mata pelajaran PKn Kelas III di SD Negeri 4 Tanjung Kamal Tahun Pelajaran 2018/2019 sangat efektif. 2). Penerapan pendekatan scientific berbasis pembelajaran aktif same different dapat meningkatkan hasil belajar siswa mencapai $16 \%$ sub tema Norma di masyarakat mata pelajaran PKn Kelas III di SD Negeri 4 Tanjung Kamal Tahun Pelajaran $2018 / 2019$.
\end{abstract}

Kata Kunci : Pendekatan scientific berbasis pembelajaran aktif same different, Hasil Belajar

\section{PENDAHULUAN}

Dalam proses belajar mengajar PKn di SD Negeri 4 Tanjung Kamal, terutama kelas III selama ini yang telah dilaksanakan oleh seorang guru belum mencapai kreteria, sebagian belum memenuhi KKM yang telah ditentukan. Contoh pada saat ulangan umum semester ganjil yang memenuhi KKM hanya 
70\%. Minat belajar siswa semakin menurun karena sibuk main HP terutama pada malam hari tidak ingat belajar lagi, sehingga pada waktu proses pembelajaran berlansung ada yang mengantuk kurang memperhatikan dan kurang konsentrasi. Bila guru bertanya kebanyakan belum berani menjawab. Adapun yang mempunyai keberanian menjawab tetapi tidak sesuai apa yang diharapkan, maka guru harus merubah suasana yang menyenangkan, menggairahkan dan bersemangat. Selama ini pembelajaran menggunakan metode ceramah dan tanya jawab, siswa mengalami kesan yang membosankan, ada yang tidak memperhatikan, hanya berbicara dengan teman kanan kiri nya.

Di SD Negeri 4 Tanjung Kamal sebagian besar siswa kurang motifasi dari orang tuanya, karena sibuk bekerja. Sehingga orang tua tidak sempat memperhatikan dan memantau perkembangan anakya. Selain itu proses pembelajaran lebih berorientasi pada penyelesaian materi pada buku dan guru belum menerapkan pembelajaran yang berhubungan dengan konteks lingkungan siswa keadaan ini membuat siswa relatif pasif selama pembelajaran berlangsung. Salah satu upaya untuk mewujudkan pembelajaran tersebut adalah menerapkan pembelajaran aktif dengan same different. Dengan menggunakan pembelajaran aktif dengan same different ini diharapkan ada perubahan minat belajar siswa dan akan menambah suasana yang menyenangkan. Manfaatnya daya serap yang baik, akan meningkatkan hasil belajar. Sehingga akan mencapai KKM yang sudah ditentukan. Melalui pembelajaran aktif dengan same different ini selain dapat menguasai konsep dengan baik, siswa diberi kesempatan untuk menggali berbagai informasi dan mencari sumber-sumber yang lain sehingga siswa akan mengalami sendiri dengan melihat, membaca dan melakukan. Siswa akan mempunyai kesadaran untuk membaca,menggali dari berbagai media,baik media cetak maupun dari media elektronik,bisa melaui internet,dan buku-buku yang ada diperpustakaan.

\section{METODE PENELITIAN}

Penelitian ini adalah penelitian tindakan kelas (PTK) yang bertujuan untuk meningkatkan hasil belajar siswa dalam proses pembelajaran pada PKn . Penelitian tindakan ini menggunakan dua siklus, masing-masing siklus terdiri dari empat tahap, yaitu merencanakan, melakukan tindakan, mengamati dan 
merefleksi. empat fase dalam satu siklus sebuah PTK seperti ditunjukkan dengan gambar berikut:

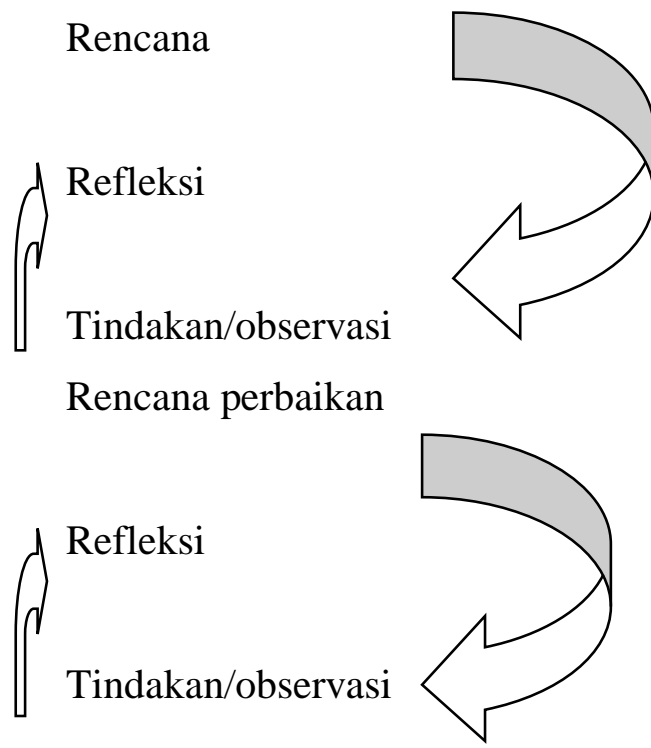

Gambar 3.1 Spiral penelitian tindakan kelas metode Hopkins (TIM pelatih Proyek PGSM 2007: 7)

Sesuai dengan gambar spiral penelitian tindakan kelas diatas penelitian ini terdiri atas empat fase yaitu perencanaan, tindakan, observasi dan refleksi.

\subsubsection{Perencanaan}

Tahap ini merupakan tahap merencanakan segala sesuatu yang akan dilakukan dalam penelitian. Kegiatan yang dilakukan dalam tahap perencanaan ini adalah sebagai berikut:

1. Menyusun rencana pembelajaran pada pokok bahasan memahami materi yang akan dibahas

2. Mempersiapkan materi berupa sub tema Norma di masyarakat

3. Mempersiapkan soal sebagai bahan diskusi di dalam kelas

4. Mempersiapkan soal tes ulangan harian untuk siswa

5. Mempersiapkan tugas pekerjaan rumah untuk siswa

6. Mempersiapkan rangkuman materi untuk dibagikan kepada siswa

7. Proses belajar mengajar dibagi menjadi tiga tahap yaitu (a) Pendahuluan, guru memberikan apersepsi tentang pentingnya pembelajaran PKn yang akan dibahas; (b) Kegiatan inti, guru mendampingi dan membimbing siswa dalam melakukan kegiatan pendekatan scientific berbasis pembelajaran aktif same different. Kegiatan pendekatan scientific berbasis pembelajaran aktif same 
different dimulai dari siswa menjelaskan materi analisis materi yang berkaitan dengan pemahaman konsep atau pengertian dari sub tema Norma di masyarakat, Mengorganisasikan siswa ke dalam kelompok belajar, dan diskusi untuk mencapai pengambilan kesimpulan; (c) Kegiatan penutup.

8. Mempersiapkan daftar pertanyaan untuk mewawancarai siswa mengenai tanggapannya terhadap pendekatan scientific berbasis pembelajaran aktif same different.

9. Membuat lembar observasi yang digunakan peneliti untuk mengamati motivasi dan hasil belajar siswa.

\subsubsection{Tindakan}

Pada tahap ini kegiatan yang dilaksanakan adalah melakukan tindakan berdasarkan pada perencanaan yang telah dibuat. Peneliti bertindak sebagai guru. Penelitian ini dilakukan dalam dua siklus dengan rincian sebagai berikut:

\section{Kegiatan Persiklus}

a. Kegiatan pendahuluan Guru memberikan apersepsi kepada siswa sesuai dengan materi yang akan dibahas.

b. Kegiatan Inti

Pada kegiatan ini peneliti menerapkan kegiatan pendekatan scientific berbasis pembelajaran aktif same different yang terdiri dari analisis materi yang berkaitan dengan pemahaman konsep atau pengertian sub tema Norma di masyarakat, mengorganisasikan siswa ke dalam kelompok belajar, dan diskusi untuk mencapai pengambilan kesimpulan dengan langkah-langkah sebagai berikut:

Langkah I: Analisis contoh sub tema Norma di masyarakat dengan pemahaman konsep

Langkah II : Membagi siswa menjadi beberapa kelompok untuk bertatap muka atau berdiskusi. Dalam satu kelompok terdiri dari dua orang siswa. Kegiatan ini termasuk unsur bertatap muka dalam pembelajaran kooperatif dan siswa memperhatikan dan 
mencatat penjelasan guru dan guru memberi lembar tugas pemahaman materi

Langkah III : Membuat pertanyaan berdasarkan masalah yang diajukan melalui gambar;

Langkah IV : Memberitahu topik;

Langkah V : Meminta siswa mencari informasi;

Langkah VI : Meminta tim untuk menjelaskan jawabannya dikelas besar

Langkah VII : setiap siswa memberikan penjelasan tentang persamaan dan perbedaan pada gambar yang guru sajikan

Langkah III: Pengambilan Kesimpulan

Guru bersama siswa menyimpulkan materi yang dibahas saat itu sampai siswa dan guru dapat memahami tujuan pelajaran yang dibahas.

c. Kegiatan penutup

Guru memberikan tugas untuk di kerjakan di rumah.

\section{Teknik Analisis Data}

Analisis data dalam penelitian ini adalah deskriptif kualitatif yaitu berusaha memaparkan proses pendekatan scientific berbasis pembelajaran aktif same different. Ketuntasan belajar siswa sebesar $80 \%$ atau lebih, maka dikatakan berhasil atau tercapai tujuan yang diinginkan untuk mencari prosentase ketuntasan belajar siswa secara klasikal digunakan rumus:

$$
\begin{gathered}
\mathrm{P}=\frac{n}{N} \times 100 \% \\
\mathrm{P}=\text { Prosentase Ketuntasan } \\
\mathrm{n}=\text { Jumlah Siswa Yang Tuntas } \\
\mathrm{N}=\text { Jumlah Seluruh Siswa }
\end{gathered}
$$

Setelah nilai hasil belajar dipresentasikan dan dicari standar ketuntasan untuk mengetahui daya serap siswa secara individu dan klasikal standar tersebut yaitu:

1. Daya serap perseorangan

Seorang siswa dikatakan telah memenuhi standar ketuntasan belajar bila mencapai nilai $\geq 70$. 
2. Daya serap klasikal

Suatu kelas dikatakan telah memenuhi standar ketuntasan belajar di kelas tersebut telah mencapai $\geq 85 \%$ dari jumlah siswa yang telah mencapai nilai $\geq$ 70.

Berdasarkan penjelasan di atas bahwa KKM di pendekatan scientific berbasis pembelajaran aktif same different yaitu 70 untuk daya serap perorangan dan daya serap klasikal yaitu $85 \%$.

\section{HASIL PENELITIAN DAN PEMBAHASAN}

Hasil observasi peneliti selama mengajar di kelas III merasakan berbeda dengan kelas yang lain. Siswa cenderung ramai disebabkan peneliti menyadari bahwa masih kurang adanya persiapan sehingga perlu adanya perbaikan tindakan sehingga hasil belajar siswa mencapai optimal. Hasil observasi peneliti dapat dilihat pada tabel berikut:

Nilai Prasiklus

\begin{tabular}{|l|c|c|}
\hline \multicolumn{1}{|c|}{ Nilai } & Jumlah Siswa & Persentase \\
\hline Siswa Tuntas $(\geq 70)$ & 12 & $55 \%$ \\
\hline Siswa Tidak Tuntas $(<70)$ & 10 & $45 \%$ \\
\hline Jumlah & 22 & $100 \%$ \\
\hline
\end{tabular}

Siklus 1 bahwa mencapai ketuntasan secara klasikal mencapai $77 \%$ atau 17 siswa yang tuntas. Nilai rata-rata hasil belajar mencapai 75 sehingga perlu adanya siklus 2 tidak hanya mencapai ketuntasan secara klasikal, hasil belajar siswa pada siklus 1 dapat dilihat pada tabel berikut:

Nilai Siklus 1

\begin{tabular}{|l|c|c|}
\hline \multicolumn{1}{|c|}{ Nilai } & Jumlah Siswa & Persentase \\
\hline Siswa Tuntas $(\geq 70)$ & 17 & $77 \%$ \\
\hline Siswa Tidak Tuntas $(<70)$ & 5 & $23 \%$ \\
\hline Jumlah & 22 & $100 \%$ \\
\hline
\end{tabular}

Peneliti menggunakan catatan bebas dalam melakukan pengamatan secara umum mengenai tingkah laku anak pada saat melaksanakan tes. Hasilnya semua 
siswa masuk mengikuti tes, masih ada 2 anak yang bersikap kebingungan meminta bantuan temannya terutama yang duduk di belakang anak ini tergolong nakal sering bolos. Guru dan peneliti sama-sama menggunakan catatan bebas. Setelah melakukan peninjauan pada setiap siswa terlihat mereka mulai memperhatikan kerapian dalam menulis, ada yang mulai berfikir dengan kritis mereka tidak malu lagi ketika dilihat hasil pekerjaannya. Secara garis besar ulangan atau pelaksanaan tes pada siklus I berjalan dengan lancar dan tertib. Hasil belajar pada siklus II mencapai ketuntasan secara klasikal sebesar 91\% atau sebanyak 20 siswa. Dapat dilihat pada tabel berikut:

Rekapitulasi Hasil Belajar Prasiklus, Siklus I dan Siklus II

\begin{tabular}{|l|c|c|c|c|c|c|}
\hline \multirow{2}{*}{ Nilai } & \multicolumn{2}{|c|}{ Prasiklus } & \multicolumn{2}{c|}{ Siklus 1 } & \multicolumn{2}{c|}{ Siklus 2 } \\
\cline { 2 - 6 } & Jumlah/Prosentase & \multicolumn{2}{c|}{ Jumlah/Prosentase } & \multicolumn{2}{c|}{ Jumlah/Prosentase } \\
\hline$\geq 70$ & 12 & $55 \%$ & 17 & $77 \%$ & 20 & $91 \%$ \\
\hline$<70$ & 10 & $45 \%$ & 5 & $23 \%$ & 2 & $9 \%$ \\
\hline Jumlah & 22 & $100 \%$ & 22 & $100 \%$ & 22 & $100 \%$ \\
\hline
\end{tabular}

Hasil observasi terhadap guru pada siklus II yang dilakukan oleh peneliti dalam pembelajaran menunjukkan, aktivitas guru sebagai fasilitator kekurangan dalam siklus I sudah teratasi berkat kerjasama tim peneliti. Guru memberikan semangat, penguatan dan pengakuan atas usaha siswa dalam pembelajaran, baik dalam membimbing siswa kepada siswa saat mengalami kesulitan menyelesaikan soal. Guru dalam melaksanakan Pendekatan scientific berbasis pembelajaran aktif same different sesuai dengan skenario pembelajaran berpedoman pada indikator aktivitas guru mengajar, maka guru dalam menggunakan Pendekatan scientific berbasis pembelajaran aktif same different dapat dikategorikan baik.

Kegiatan pada siklus I dan hasil siklus perbaikan pada siklus II semakin mantap, Artinya hanya sedikit kendala yang dihadapi oleh peneliti hal ini disebabkan siswa yang menunjuk sendiri teman yang pantas. Berdasarkan analisis terhadap observasi dapat Diketahui bahwa siswa merasa antusias dan semangat saat presentasi si guru berlangsung. Antusias dan ketertarikan siswa terlihat dalam hal mengeluarkan pendapat dan bertanya saat guru memberikan presentasi mengenai manfaat mempelajari materi. Siswa mulai menunjukkan peningkatan 
kemampuan berfikir kreatif dalam mengerjakan soal-soal. Guru memotivasi siswa dengan menginformasikan bahwa nilai yang telah mereka peroleh saat pelaksanaan siklus I yang masih rendah, sehingga memunculkan dorongan kepada mereka untuk berusaha meningkatkan hasil belajar pada siklus II.

\section{PEMBAHASAN}

Selama pelaksanaan penerapan Pendekatan scientific berbasis pembelajaran aktif same different, siswa tampak aktif dan antusias dalam mengikuti kegiatan belajar mengajar. Pada pelaksanaan siklus I diikuti oleh 22 siswa. Tes terakhir menunjukkan ketuntasan klasikal mencapai 77\%. Dari 22 siswa tersebut ada 10 orang yang masih mendapat nilai dibawah 70 . dalam pelaksanaan tes ada beberapa siswa yang tidak masuk, hal ini juga mempengaruhi ketuntasan belajar.

Kesimpulan yang diperoleh adalah pelaksanaan pembelajaran pada siklus 1 belum berhasil maka penelitian dilanjutkan pada siklus II hal ini disebabkan oleh siswa masih bingung dengan model pembelajaran yang guru terapkan padahal masing-masing siswa diberikan kartu indek yang berisi materi pelajaran. Pada siklus II, tetap diikuti oleh 22 siswa dan hasil pelaksanaan tes diperoleh ada 2 siswa yang belum tuntas belajarnya, sedangkan ketuntasan belajar secara klasikal baik yang ditunjukkan semakin antusiasnya siswa dengan Pendekatan scientific berbasis pembelajaran aktif same different.

Pada hasil belajar siswa pada siklus II sudah mengalami peningkatan dari siklus sebelumnya, meskipun peningkatannya tidak terlalu tinggi dikarenakan dalam mengerjakan tugas kurang teliti.

Peningkatan hasil belajar siswa menunjukkan bahwa penerapan Pendekatan scientific berbasis pembelajaran aktif same different dapat dipertimbangkan sebagai pendekatan pembelajaran yang baik diterapkan pada mata pelajaran PKn yang sangat berkaitan dengan kehidupan sehari-hari. Keunggulan pembelajaran dengan menggunakan penerapan Pendekatan scientific berbasis pembelajaran aktif same different pada penerapannya yang melibatkan siswa secara aktif dalam proses belajar mengajar dan mendorong siswa untuk memperoleh pengetahuannya sendiri tanpa selalu tergantung pada guru, meningkatkan konsentrasi dan pengetahuan siswa melalui pembelajaran yang 
bersifat afektif. Serta menumbuhkan kreativitas siswa dalam berfikir, saling bertukar pikiran, mampu mengemukakan ide-ide atau pendapat yang sesuai dengan wawancara yang berkaitan dengan materi yang dibahas dan melatih siswa untuk lebih aktif dalam bertanya dan menjawab pertanyaan-pertanyaan baik dari guru maupun dari siswa lain. Kelemahan penerapan Pendekatan scientific berbasis pembelajaran aktif same different adalah guru kesulitan dalam pengelolaan kelas dan waktu.

\section{KESIMPULAN}

Penerapan pendekatan scientific berbasis pembelajaran aktif same different sub tema Norma di masyarakat mata pelajaran PKn Kelas III di SD Negeri 4 Tanjung Kamal Tahun Pelajaran 2018/2019 sangat efektif. Penerapan pendekatan scientific berbasis pembelajaran aktif same different dapat meningkatkan hasil belajar siswa mencapai $14 \%$ pada siklus 1 ketuntasan $77 \%$ sedangkan siklus 2 menjadi 91\% sub tema Norma di masyarakat mata pelajaran PKn Kelas III di SD Negeri 4 Tanjung Kamal Tahun Pelajaran 2018/2019. 


\section{DAFTAR PUSTAKA}

Gagne. 2005. Essentials of learning for instruction. Boston

Jamaris. 2006. Psikologi Belajar. Jakarta: Raja Grafindo Persada

Mudjiono. 2000. Interaksi dan Motivasi Belajar Mengajar.Jakarta: Rajawali

Muhibbin, 2003. Model Pembelajaran Menciptakan Proses Belajar Mengajar yang Kreatif dan Efektif. Jakarta, Bumi Aksara

Nasution. 2007. Mencari strategi pengembangan pendidikan nasional menjelang abad XXI. Jakarta: Grasindo

Ningtiash. 2007. Dasar-Dasar Kependidikan. Jakarta: Ditjen Bimbaga Islam

PGSM. 2007. [online]. Tersedia: http://meipanda.blogspot.com/2013/05/strukturpendukung-keanekaragaman.html

Purwanti. 2006. Psikologi pendidikan: Materi pendidikan bimbingan konseling di Perguruan Tinggi. Yogyakarta: Depdikbud

Sanjaya. 2008. Psikologi Pendidikan Jakarta PT. Rineka Cipta

Sardiman. 2003. Belajar dan faktor-faktor yang mempengaruhinya. Jakarta: PT Rineka cipta

Syaiful Bahri Djamarah. 2003. Psikologi Pendidikan Jakarta PT. Rineka Cipta

Sudjana. 2000. Metode dan teknik pembelajaran partisipatif. Jakarta: Falah Production

Sudjana. 2005. Psikologi Pendidikan dengan pendekatan Baru. Bandung: PT Remaja Rosdakarya

Suprayekti. 2003. Proses belajar Mengajar. Jakarta : PT.Bumi Aksara

Tabrani dkk. 2002. Psikologi pendidikan II. Jakarta:FEUI

Trinandita. 2004. Evaluasi diri demi peningkatan mutu pendidikan. Jakarta: Grasindo

Zaini. 2008. Cooperative Learning. Yogyakarta: Pustaka Belajar 